\title{
Knowledge and perception regarding the issues, opportunities and practices of public health among Ayurveda interns in India
}

\author{
Janmejaya Samal ${ }^{1}$, Ashwini. Ku. Pratap ${ }^{2}$ \\ ${ }^{1}$ District Epidemiologist, District Health Office, Gadchiroli, Maharashtra, India. ${ }^{2}$ Assistant Professor, Community Medicine, \\ Rajib Gandhi Institute of Medical Sciences, Srikakulum, AP, India.
}

\section{Letter to Editor}

The Indian system of medicine is a relic of great antiquity. It is the culmination of Indian ideas of medicine which represent a way of healthy living, valued with a long cultural history from our scriptures/sages which gave us the science of Ayurved, Sidha, Yoga and Naturopathy, and also the amalgamation of the best aspects of the influences of the other civilizations that its people came into contact with, be it Greece (resulting in Unani medicine) or Germany (Homoeopathy). Like the multifaceted culture of India, the traditional medicine and practices have evolved over centuries. ${ }^{1}$ Public health "is the art and science of promoting health, preventing disease and prolonging life through organized community efforts". ${ }^{2}$ It has a great role to play in any community and nation. It is believed that an effective public health system is expected to render a healthy community. This is highly influenced by its infrastructure, workforce, policies, management, implementation, and effectiveness of planning strategies.

The public health workforce includes technical workforces such as qualified doctors, nurses, lab technicians, and, occasionally, other personnel like experts in healthcare management, health policy, economics and law. ${ }^{3}$ Among the doctors, especially in the Indian public health system, a special indigenous group of doctors called the AYUSH (Ayurveda, Yoga \& Naturopathy, Unani, Siddha and Homoeopathy) doctors play a crucial role in delivering healthcare. In fact, India is the only country to legalize these indigenous systems of medicines parallel to the modern/allopathic system of medicine. ${ }^{4,5}$

Recently the National Rural Health Mission (NRHM) introduced a concept called the 'Mainstreaming of AYUSH and revitalization of local health traditions', which involved AYUSH doctors in the delivery of health care. ${ }^{6}$ In this system, the AYUSH doctors are collocated at various health facilities, such as primary health centers and community health centers, within 18 states. They are tasked with involvement in various curative, preventive and promotive health services. ${ }^{6}$ The academic syllabus of the Ayurveda stream do not cover the knowledge of any current issues in public health, as evidenced from the text books of 'Swathavrita Vijnan'. 'Swathavrita Vijnan' is one of the subjects taught at undergraduate level to
Ayurveda students in India and is accepted as the subject equivalent to community medicine. ${ }^{7}$ In this context a study was aimed at assessing the knowledge and perceptions of the issues, opportunities and practices of public health among Ayurveda interns in India.

The study was conducted in two Government Ayurveda colleges in the state of Odisha, India: the Government Ayurved College, Bolangir, and the KATS Government Ayurved College, Ankuspur, Ganjam. The state of Odisha has three Govt. Ayurveda colleges but in this study only two colleges were selected purposefully for the convenience of the study. For the same reason, despite there being 30 interns per college, only 20 were chosen from each one based on their interest and consent of participation in the study. A Questionnaire was used to collect the data on basic concepts of public health issues, opportunities, practices and career preferences. The questionnaire consisted of 13 questions. Permission to conduct the study was sought from the head of both the institutions before commencing.

The details of the knowledge and perceptions of public health and the career preferences of Ayurveda graduates are shown in Table 1 . The study revealed that $77.5 \%$ of interns understand the concept of public health, as they could define it in their own way. More than $82 \%$ of interns know that they study a subject equivalent to public health ('Swathavritta Vijnan') at undergraduate level, and were able to mention various disciplines of public health. More than $67 \%$ of interns could relate to the importance of public health as AYUSH doctors and $65 \%$ of interns could mention the current issues of public health in India. However, only $5 \%$ of the respondents could answer various public health institutions in India for higher studies.

Sixty five percent of interns suggested a change in their academic curriculum in line with the healthcare needs of the country. Though $70 \%$ of interns were interested in a career in public health, $95 \%$ of the interns were unaware of possible career prospects in the field of public health, and $92.5 \%$ of interns were not aware of the IPHS (Indian Public Health Standards) (Table 2).

Correspondence: Dr. Janmejaya Samal, District Epidemiologist, District Health Office, Gadchiroli, Maharashtra, India, E-mail: janmejaya_samal@yahoo.com, jaytheworld@gmail.com. 
Table 1: Participants' response to public health

\begin{tabular}{|l|c|c|c|}
\hline \multirow{2}{*}{ The interns have knowledge regarding: } & \multicolumn{3}{|c|}{ Response of the participants } \\
\cline { 2 - 3 } Concepts of Public Health & Correct & Incorrect & No idea \\
\hline Study of public health at UG level & $77.5 \%$ & $22.5 \%$ & - \\
\hline Equivalent subject of PH in your curriculum & $82.5 \%$ & $17.5 \%$ & - \\
\hline Various disciplines of public health & $82.5 \%$ & $17.5 \%$ & - \\
\hline Relevance of public health as a doctor & $82.5 \%$ & $17.5 \%$ & - \\
\hline Current issues of public health in India & $67.5 \%$ & $32.5 \%$ & - \\
\hline Institutes to study public health in India & $65 \%$ & $35 \%$ & - \\
\hline Relationship to Indian Public Health Standards (IPHS) & $5 \%$ & $95 \%$ & - \\
\hline Involvement of Ayurveda doctors in public health programs & $7.5 \%$ & $92.5 \%$ & - \\
\hline
\end{tabular}

Table 2: Curriculum change and career preferences

\begin{tabular}{|l|c|c|c|}
\hline \multirow{2}{*}{ Items } & \multicolumn{2}{|c|}{ Response of the participants } \\
\cline { 2 - 4 } & Yes & No & No idea \\
\hline Need to change the curriculum & $65 \%$ & $27.5 \%$ & $7.5 \%$ \\
\hline Career prospects of public health in India & $5 \%$ & $95 \%$ & - \\
\hline Interest in pursuing a career in public health & $70 \%$ & $25 \%$ & $5 \%$ \\
\hline
\end{tabular}

Regarding the involvement of AYUSH doctors, $65 \%$ of interns indicated the knowledge of involvement in the field of public health.

Ayurveda is the most commonly practiced form of complementary and alternative medicine in India. ${ }^{8}$ About $80 \%$ of Indian patients use Ayurvedic therapy. ${ }^{9}$ It is evident from studies that the discipline is also becoming popular among allopathic doctors, however they had little knowledge about Ayurveda and Ayurvedic medicine. $^{8}$ A survey found that $15 \%$ of patients receiving allopathic treatments also received herbal or Ayurvedic products, and $40 \%$ of those patients experienced potential adverse herb-drug interactions. ${ }^{10}$ There is an urgent need to review the Ayurveda curriculum to incorporate public health issues, and to integrate Ayurveda and modern medicine more closely together in order to provide more effective treatment for the patients (leading to an increase in patient satisfaction). ${ }^{8}$

Like most developing countries, India also has a shortage of personnel in the health workforce. Different systems of medicine, including Ayurveda and other disciplines, should be developed to provide public health to the unserved and underserved population of India. ${ }^{4}$ The AYUSH graduates should be adequately equipped with knowledge of public health concepts, principles and issues so that they may competently handle them later in their professional life. The Government's recognition of indigenous systems of medicine also encouraged the AYUSH doctors to build career in public health and which is facilitated by increase in the access to information, the awareness of job opportunities, and a great degree of professional and personal satisfaction. ${ }^{11}$ It is indeed high time to recognize the huge potential of Ayurveda and other indigenous systems of medicine, and these methods should be used to supplement modern medicine in providing universal healthcare to the people. The paucity of the public health workforce could be replenished to a great extent with such recognition and appreciation.

\section{Acknowledgement}

We are extremely thankful to Prof. (Dr) P K Nathsharma, Principal, KATS Govt. Ayurved College, Ankushpur, Ganjam, Orissa and Prof. (Dr) B N Mohapatra, Principal Govt. Ayurved College, Bolangir, Orissa for their cooperation and kind permission for conducting the study in both the colleges. We are greatly obliged to the extreme support and cooperation rendered by the interns of both the colleges while conducting the study.

\section{References}

1. Department of AYUSH. AYUSH in India 2010. New Delhi: Ministry of Health and Family Welfare, 2011.

2. Winslow CEA. The untitled field of public health. Mod Med 1920; 2:183-91.

3. Turnock BJ. Public Health: What it is and how it Works? $4^{\text {th }}$ Edition, Sudbury, Massachusetts: Jones and Bartlett Publishers, 2009.

4. Samal J. What makes the ayurveda doctors suitable public health workforce? Int J Med Sci Public Health 2013;2(4):919-23.

5. Ministry of Health and Family Welfare. National Health policy-2002. New Delhi: Ministry of Health and Family Welfare, 2002.

6. Ministry of Health and Family Welfare. National rural health mission (2005-2012). Mission Document. New Delhi: Ministry of Health and Family Welfare, 2005. 
7. Singh RH. Swasthavrita Vijnan. Baranasi: Choukhamba Surya Bharati Prakasan, 2009.

8. Gawde SR, Shetty YC, Pawar DB. Knowledge, attitude, and practices toward ayurvedic medicine use among allopathic resident doctors: A cross-sectional study at a tertiary care hospital in India. Perspect Clin Res 2013;4:175-80
9. Verma U. Allopathic vs. Ayurvedic practices in tertiary care institutes of urban North India. Indian J Pharmacol 2007;9:52-4.

10. Izzo A, Ernst E. Interactions between herbal medicines and prescribed drugs: An updated systematic review. Drugs 2009;69:1777-98.

11. Samal J. Public health and allied career choices for AYUSH graduates in India. Global $\mathrm{J}$ Med Public Health 2013;2( 4):1-7. 